\title{
Groundwater Vulnerability Assessment in Karst Areas Based on Analytic Hierarchy Process- A Case Study in Weining County, China
}

\author{
$\mathrm{Bo} \mathrm{Li}^{*}$ \\ Key Laboratory of Karst Environment and Geohazard Prevention, Ministry of Education, Guizhou University, Guiyang, \\ Guizhou 550000, China
}

\begin{abstract}
Strong karstlize effect forming surface and underground double-space structure in karst area, what resulting groundwater systems are extremely sensitive to outside interference. This article mainly focuses on the vulnerability assessment of karst groundwater, proposing that the vulnerability assessment of karst groundwater should be considered from three perspectives: the inherent vulnerability of groundwater, the vulnerability of the ecological environment and water resources carrying capacity, and selecting 19 indicators based on it, establishing the index system and evaluation method of groundwater vulnerability assessment in karst area combines with Analytic Hierarchy Process. The article apply the evaluation method to evaluate groundwater vulnerability of typical karst area-Weining county, China. The study can provide certain reference for the groundwater vulnerability assessment in similar karst area.
\end{abstract}

Keywords: Analytic hierarchy process, groundwater, karst area, vulnerability assessment.

\section{INTRODUCTION}

Water is the irreplaceable, basic and natural resource, which also is the controlling factor of the ecological environment development, human survival and production development as well as the virtuous cycle of ecosystem are all inseparable from water. Dates shows that the world's population is increasing with an annual increase rate of nearly 100 million at present, couple with the rapid development of economy and society, resulting in global water consumption increased by three times in recent 50 years, however, within a certain range of space and time, water resource is limited, a series of water problems such as water shortage, water pollution, etc. have become a serious challenge that human beings has to confront [1-3]. The karst area as the main representative particularly, these problems are more prominent for the karst area, which occupies about $15 \%$ world land area, about 22 million square kilometers, living about 1 billion people and providing drinking water for a quarter of the world's population. But because of the unique geological and hydrological background of the karst area, carbonate rocks in karst area are widely exposed, strong karstlize effect forming surface and underground double-space structure, causing regional water distribution extremely uneven. In additional, the weathering of lava is dominantly chemical dissolution, leaving very small soil substance, resulting in innately barren soil, and left a stone sea (rocky) if erosion slightly, the ecological environment is very fragile. At the same time, due to the lack of natural seepage layer, the surface water and contamination is easily to go into aquifer or underground river directly through caves and pipes, the karst aquifer is vulnerable to be polluted, and the retention time of pollutants in the karst system is short, therefore, the attenuation of contaminants, chemical and biological recession effect often is invalid. Given the above characters of the groundwater resource in karst area, making groundwater vulnerability assessment study is conducive to take targeted measures to protect underground water in karst area better, and has important significance for the sustainable use of karst groundwater.

The concept of "Groundwater Vulnerability" is first proposed by French Margat $[4,5]$. In the whole, the development of the concept of groundwater vulnerability can be roughly divided into two phases. Before the 1980s, groundwater vulnerability is put forward based on the idea that "groundwater in a region relative to other areas of groundwater contamination is more fragile", and mostly defined from the perspective of hydrogeological internal factors. After the 1980s, People considering hydrogeological internal elements and also taking into account the impact of external factors such as human activities and the type of pollution to the groundwater vulnerability. In 1987 "the international conference on soil and groundwater vulnerability", experts proposed a variety of definitions combining with the inside and outside factors influencing the groundwater vulnerability, making the define way of groundwater vulnerability has a new breakthrough. Foster considered that the vulnerability of the aquifer and the pollution load caused by human activities resulting in groundwater pollution $[6,7]$, on this basis, he first proposed the term of "aquifer vulnerability". USEPA and IAH divided groundwater venerability into two categories in $1993[8,9]$ : one is intrinsic vulnerability that only considers Hydrogeological internal factors but not human activities and pollution source; the other is Specific Vulnerability which coming from specific pollution source or human activities. In the whole, due to involve many complex factors, couple with the current research level that yet need to be improved, the researchers tend to the claim that divide 
groundwater venerability into two species from the US National Science Research Council.

The current research of groundwater venerability on karst region is relatively less, the karst groundwater system response more sensitive to the surrounding environment change. In addition to the inherent internal factors of groundwater, ecological environment and human activities also affect the venerability. One-sided from one aspect to study the vulnerability of the water environment system can not objectively reflect the overall vulnerability of regional water system $[10,11]$. The relationship between the three is interdependent and mutual restrain, and forming an interacting complex system. So the impact factors of groundwater venerability assessment should comprehensively consider the inherent vulnerability of the groundwater, the vulnerability of ecological environment and the vulnerability of water resources carrying capacity. This article just establish the index system of karst groundwater venerability assessment on the basis of the three aspects, and take typical karst mountain area of southwestern China-Weining county as an example to make groundwater vulnerability assessment, which can provide reference and basis for research in similar areas.

\section{EVALUATION INDEX SYSTEM}

The index system of venerability assessment is a complex system, three points should be mainly noticed in the establishment, the one is that the index should be able to reflect key factors that influencing groundwater venerability, the second is that the index could embody essential problem of groundwater venerability, and the third is that the index should have maneuverability. This paper choose responding index mainly from three angles of the inherent vulnerability of groundwater, the vulnerability of ecological environment and the vulnerability of water resources carrying capacity, and build up karst groundwater venerability evaluation index system in karst region.

According to the analysis of main control factors that affecting the venerability of groundwater in karst area, the study is divided into three levels. As the final goal, groundwater venerability assessment in karst area is the goal layer of the model (A layer); the inherent vulnerability of groundwater, the vulnerability of ecological environment and the vulnerability of water resources carrying capacity determine the possibilities of venerability, but the influence mode need through relevant specific factors to reflect, this is the intermediate link of problem solving, which is the criterion layer of the model (B layer); the index of the control factors make up the index layer of the model (C layer), and ultimately achieve the desired objectives by the problem decision in this level (Table 1).

\section{ASSESSMENT METHOD}

Each single-phase indicator in index system of the groundwater venerability assessment reflects the groundwater venerability situation from different angles, thus must evaluate comprehensively, this paper use the multi-index linear weighting function method to make evaluation, the model is as follows:

$\mathrm{Vi}=\sum \mathrm{Fj} \times \mathrm{Wj}$

$\mathrm{V}$ represents groundwater venerability comprehensive index value of study area; $\mathrm{Fj}$ is the system index value of the jth subsystem; $\mathrm{Wj}$ represents the weight of the jth subsystem.

$\mathrm{Fj}=\sum \mathrm{Ijk} \times \mathrm{Wjk}$

Ijk represents the value of the k-th index in the $j$-th subsystem (post-treatment); $\mathrm{Wjk}$ represents the weight of the kth index in the $\mathrm{j}$-th subsystem.

$\mathrm{Wk}=\mathrm{Wj} \times \mathrm{Wjk}$

Wk represents the weight of the k-th index in the whole evaluation system.

We can reach to the result from above:

$\mathrm{V}=\sum \mathrm{Fj} \times \mathrm{Wj}=\sum \mathrm{Ijk} \times \mathrm{Wjk} \times \mathrm{Wj}=\sum \mathrm{Ik} \times \mathrm{Wk}$

The index value quantization is determined according to the criteria of Table $\mathbf{2}$, directed indicators are divided into

Table 1. Groundwater vulnerability assessment index system in karst areas.

\begin{tabular}{|c|c|c|c|}
\hline $\begin{array}{c}\text { Goal layer (A) } \\
\text { Criterion layer (B) }\end{array}$ & $\begin{array}{l}\text { The inherent vulnerability of } \\
\text { groundwater (B1) }\end{array}$ & $\begin{array}{l}\text { The vulnerability of water resources carrying capac- } \\
\text { ity (B2) }\end{array}$ & $\begin{array}{l}\text { The vulnerability of ecological envi- } \\
\text { ronment (B3) }\end{array}$ \\
\hline \multirow{5}{*}{ Index layer (C) } & Groundwater depth $(\mathrm{C} 1)$ & Groundwater resource scale (C7) & Rock decertification ratio $(\mathrm{C} 15)$ \\
\hline & $\begin{array}{l}\text { The type of aquifer me- } \\
\text { dium (C2) }\end{array}$ & The utilization ratio of groundwater (C8) & Vegetation coverage $(\mathrm{C} 16)$ \\
\hline & Vadose zone (C4) & $\begin{array}{l}\text { Water consumption rate of ten thousand industry } \\
\text { output }(\mathrm{C} 10)\end{array}$ & Soil erosion $(\mathrm{C} 18)$ \\
\hline & Groundwater recharge (C5) & Water consumption unit of GDP (C11) & Drought index (C19) \\
\hline & The terrain slope $(\mathrm{C} 6)$ & Water consumption per capita(C12) & \\
\hline
\end{tabular}


Table 2. Scoring criteria of karst groundwater vulnerability assessment index.

\begin{tabular}{|c|c|c|c|c|c|c|}
\hline \multirow{2}{*}{ Category } & \multirow{2}{*}{ Range } & $\begin{array}{c}\text { Strongest } \\
\text { venerability }\end{array}$ & $\begin{array}{c}\text { Stronger } \\
\text { venerability }\end{array}$ & $\begin{array}{c}\text { Mid } \\
\text { venerability }\end{array}$ & $\begin{array}{c}\text { Weak } \\
\text { venerability }\end{array}$ & $\begin{array}{c}\text { Non } \\
\text { venerability }\end{array}$ \\
\cline { 3 - 7 } & I degree & II degree & III degree & IV degree & V degree \\
\hline \hline \multirow{2}{*}{ Positive indicator } & Value range & $\leq \mathrm{a} 1$ & $\mathrm{a} 1 \sim \mathrm{a} 2$ & $\mathrm{a} 1 \sim \mathrm{a} 2$ & $\mathrm{a} 1 \sim \mathrm{a} 2$ & $3 \sim 4$ \\
\cline { 2 - 7 } & Scores range & 1 & $1 \sim 2$ & $2 \sim 3$ & $\mathrm{~b} 1 \sim \mathrm{b} 2$ & $\leq \mathrm{b} 1$ \\
\hline \multirow{2}{*}{ Reverse indicator } & Value range & $\geq \mathrm{b} 4$ & $\mathrm{~b} 3 \sim \mathrm{b} 4$ & $\mathrm{~b} 2 \sim \mathrm{b} 3$ & $2 \sim 4$ & 4 \\
\cline { 2 - 7 } & Scores range & 1 & $1 \sim 2$ & $2 \sim 3$ & 4 \\
\hline
\end{tabular}

positive and reverse indicators in the basis of the contribution of the index to the system. Positive indicator refers to the indicators that the larger the value, the better, such as groundwater scale; reverse indicators is the opposite, the smaller the value, the better, such as soil erosion intensity. The paper set $\mathrm{a} 1<\mathrm{a} 2<\mathrm{a} 3<\mathrm{a} 4$ as grade values for positive indicators; and $\mathrm{b} 1<\mathrm{b} 2<\mathrm{b} 3<\mathrm{b} 4$ for reverse indicators.

According to the index marking standard in the Table 2, we make quota measurement by the linear quantification method. Let $\mathrm{p}$ is scoring value, $\mathrm{x}$ is the actual value of the index, we have the following index quantification formula:

(1) I degree indicator

For positive indicator, when $\mathrm{x} \leq \mathrm{a} 1, \mathrm{p}=1$

For reverse indicator, when $\mathrm{x} \geq \mathrm{b} 4, \mathrm{p}=1$

(2). II degree indicator

When $\mathrm{x}$ is positive indicator,

$\mathrm{p}=1+(\mathrm{x}-\mathrm{a} 1) /(\mathrm{a} 2-\mathrm{a} 1)$

When $\mathrm{x}$ is reverse indicator,

$\mathrm{p}=1+(\mathrm{b} 4-\mathrm{x}) /(\mathrm{b} 4-\mathrm{b} 3)$

(3). III degree indicator

When $\mathrm{x}$ is positive indicator,

$\mathrm{p}=2+(\mathrm{x}-\mathrm{a} 2) /(\mathrm{a} 3-\mathrm{a} 2)$

When $\mathrm{x}$ is reverse indicator,

$\mathrm{p}=2+(\mathrm{b} 3-\mathrm{x}) /(\mathrm{b} 3-\mathrm{b} 2)$

(4). IV degree indicator

When $\mathrm{x}$ is positive indicator,

$\mathrm{p}=3+(\mathrm{x}-\mathrm{a} 3) /(\mathrm{a} 4-\mathrm{a} 3)$

When $\mathrm{x}$ is reverse indicator,

$\mathrm{p}=3+(\mathrm{b} 2-\mathrm{x}) /(\mathrm{b} 2-\mathrm{b} 1)$

(5). V degree indicator

For positive indicator, when $\mathrm{x} \geq \mathrm{a} 5, \mathrm{p}=4$.

For reverse indicator, when $\mathrm{x} \leq \mathrm{b} 1, \mathrm{p}=4$.

\section{DETERMINE METHOD OF INDEX WEIGHT}

The determination of factor index weight in this paper use Analytic Hierarchy Process (AHP), be put forward by operation researcher of U.S.A. Saaty in 1980s, AHP is a de- cision making method of practical and multi-program or multi-objective [12]. Its main feature is that it reasonably combines qualitative and quantitative decisions together, making decision process hierarchical and quantitative in accordance with the laws of thinking and psychology. The method is rapidly applied in various fields of the social economy for the advantage of system and flexible and concise as well as the character that process various decision factors by the combination of qualitative and quantitative, such as energy systems analysis, urban planning, economic management, research evaluation etc. both has been noticed and used widely, the detailed steps include (Fig. (1)):

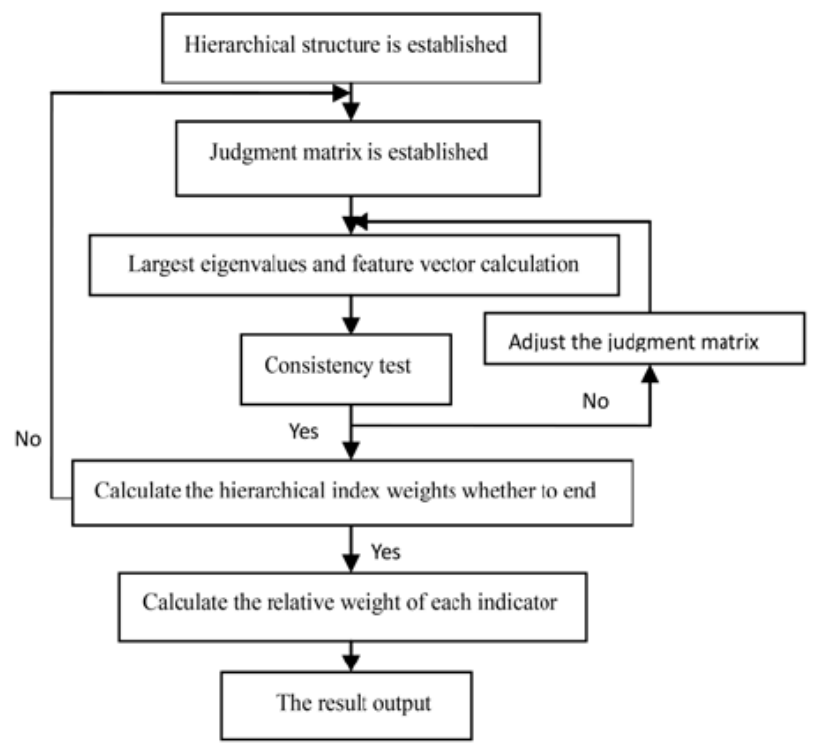

Fig. (1). Weight calculation flow chart.

(1) Make the complex issue hierarchical and form a hierarchical structure composed by the target layer, criteria layer and index layers, in which the index layer elements are affiliated to the one or more elements of criteria layer;

(2) Adopt "1-9 scale method" to form a judgment matrix (Table 3);

(3) Test the consistence of the judgment matrix;

(4) Get the weight of the index layer to the target layer weight by calculating layer by layer. 
Table 3. The meaning of 1-9 scale.

\begin{tabular}{|l|l|}
\hline Scale & Meaning \\
\hline \hline 1 & $\begin{array}{l}\text { The two compared elements has the same impor- } \\
\text { tance }\end{array}$ \\
\hline 3 & $\begin{array}{l}\text { Two elements compares, one is slightly more } \\
\text { important than the other }\end{array}$ \\
\hline 5 & $\begin{array}{l}\text { Two elements compares, one is obviously more } \\
\text { important than the other }\end{array}$ \\
\hline 7 & $\begin{array}{l}\text { Two elements compares, one is strongly more } \\
\text { important than the other }\end{array}$ \\
\hline $\begin{array}{l}\text { The reciprocal of } \\
\text { two, four, six, eight }\end{array}$ & $\begin{array}{l}\text { Two elements compares, one is extremely more } \\
\text { important than the other } \\
\text { the both, take the middle value of the adjacent } \\
\text { judgments above }\end{array}$ \\
\hline
\end{tabular}

\section{APPLICATION EXAMPLE}

\subsection{Background Location and Topography Situation}

Weining county located in the most west of Guizhou province in China, the east is Hezhang county, the west is Zhao tong, Ludian, Huize county of Yunnan province, the south is Xuanwei county of Yunnan province, the north is Yiliang county of Yunnan province (Fig. (2)) the geography coordinate is $103^{\circ} 35^{\prime} 52^{\prime \prime} \sim 104^{\circ} 15^{\prime} 00^{\prime \prime} \mathrm{E}$ and $26^{\circ} 30^{\prime} 34^{\prime \prime} \sim 27^{\circ} 26^{\prime} 53^{\prime \prime} \mathrm{N}$, what is $64.57 \mathrm{~km}$ long, $86.15 \mathrm{~km}$ wide and the total area of $4366.9 \mathrm{~km} 2$. The study area is on the YunGui plateau, the overall terrain is southwest high and northeast low. The average elevation of the area is $2000 \sim$ $2400 \mathrm{~m}$, the relative height difference is $100 \sim 300 \mathrm{~m}$, the slope is big, cutting deep, and fluctuation strong. The geomorphic mainly is dissolution in the study area, and with the combination of karst hilly depression, karst hilly valley and peak cluster depression etc.

\subsubsection{Meteorological and Hydrological Situation}

Weining county is subtropical mansoon climate, with the average rainfall of $903 \mathrm{~mm}$, the maximum annual rainfall of $1198.1 \mathrm{~mm}$ (1983) and the minimum 554.7mm (1989), and the rainfall of May to October accounts for $88 \%$ of total rainfall throughout the year.

The survey area belongs to the two basin of Yangtze river and pearl river. Yangtze basin has JinSha river and kraal river, with the area of $2159 \mathrm{~km} 2$ and $1887 \mathrm{~km} 2$ separately. The pearl basin is mabai river, which is the tributary of Keduhe River and the area is $321 \mathrm{~km} 2$. There are many karst lake on the plateau surface, the biggest is Caohai with the perennial water area of $31 \mathrm{~km} 2$.

\subsubsection{The Regional Hydrogeological Situation}

The study area locates in the west of Sichuan Yunnan north-south structural zone, the north of Nanling east-west structural zone. The exposed strata are the Cambrian, Ordovician, Silurian, carboniferous, Permian and Triassic, Jurassic, Tertiary, Quaternary, without Cretaceous, among them Carboniferous and Permian are the most complete and extensive strata. The exposed rocks mainly are Shale, limestone, dolomite, quartz sandstone, basalt etc. The area of carbonate accounts for about $80 \%$ of the total rock outcropped area. Groundwater type in the area is mainly carbonate karst water. The source of groundwater recharge is atmospheric precipitation, after accepting replenishment, on the control of surface water hydrographic net and lithology as well as structure, groundwater flow in various fractures and pipelines that developed in rock body. The groundwater in the area is colorless, odorless and transparent, $\mathrm{PH}$ value is generally $7.05 \sim 7.05$, the salinity is $39.04 \mathrm{mg} / 1 \sim 541.34 \mathrm{mg} / \mathrm{l}$, total hardness $\left(\mathrm{CaCO}_{3}\right)$ usually is $21.8 \mathrm{mg} / 1 \sim 335.38 \mathrm{mg} / \mathrm{l}$, groundwater hydrochemistry type mainly is $\mathrm{HCO}_{3}-\mathrm{Ca}$ model. The vast majority of water samples were detected without ammonium ion, the NO3 level of some water samples is $1.67 \mathrm{mg} / 1 \sim 5.00 \mathrm{mg} / \mathrm{l}$, the fluoride as well as heavy metals and toxic and harmful components in the water is generally not detected or very little.

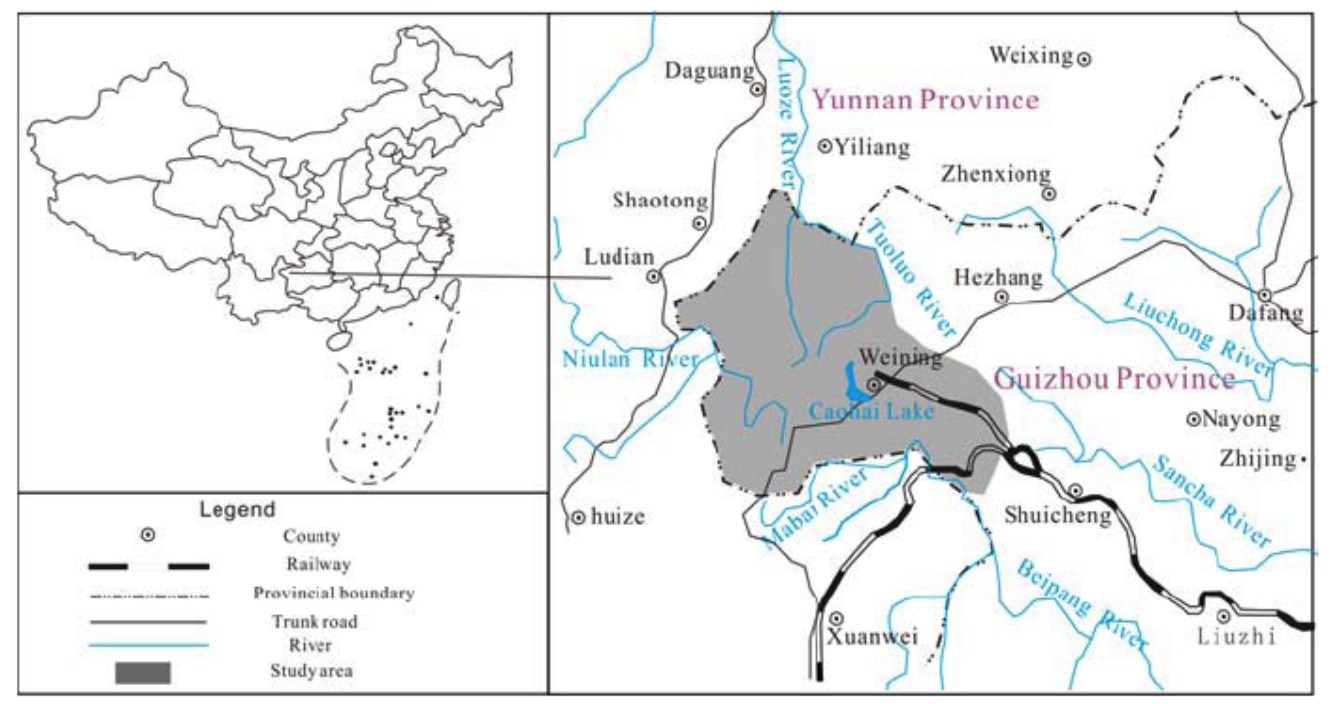

Fig. (2). Site location. 
Table 4. The quantify value of index in study area.

\begin{tabular}{|c|c|c|c|}
\hline Groundwater depth (C1) & 1.25 & Unit water consumption of GDP (C11) & 2 \\
\hline Annual renewability (C3) & 3 & The natural population growth rate $(\mathrm{C} 13)$ & 1.76 \\
\hline Vadose zone (C4) & 1.28 & The population density $(\mathrm{C} 14)$ & 3.1 \\
\hline The terrain slope (C6) & 1.21 & Vegetation coverage ratio $(\mathrm{C} 16)$ & 1.16 \\
\hline Groundwater resource scale (C7) & 2.53 & Cover thickness (C17) & 1.11 \\
\hline The utilization ratio of groundwater (C8) & 2.08 & Soil erosion $(\mathrm{C} 18)$ & 1.4 \\
\hline
\end{tabular}

\subsubsection{Social Economy and Groundwater Utilization Situa- tion}

Weining County has the total population of 1402000 , the GDP of 4962 million, the total fiscal revenue of 501.8 million, is one of the state-level poor counties. The study area is the relatively lagging economic development zone, urbanization level is low and the distribution of village and farmland is more dispersed. The industrialization degree of the most part of the study area is still in the blank state except some small mines nearby the town. The total amount of groundwater exploitation and utilization is 78.63 million $\mathrm{m} 3 / \mathrm{a}$, the utilization rate is $20.14 \%$, the utilizing quantity of rural drinking water for human and animals is 40.6630 million $\mathrm{m} 3 / \mathrm{a}$, urban domestic water consumption is 18.9989 million $\mathrm{m} 3 / \mathrm{a}$, the utilizing quantity of township industry is 17.96 million $\mathrm{m} 3 / \mathrm{a}$.

Through the visit to understand that the rural actual water consumption is $601 / \mathrm{d}$ eperson, according to the data of Weining county water conservancy bureau, the urban domestic water in the region is that county is $1001 / \mathrm{d} \cdot$ person, town is $801 /$ d person, industrial and mining enterprises in the area mainly concentrated in Chengguan town and some better economic condition townships, to estimate industrial water with reference to similar regions in the province of $369 \mathrm{~m} 3$ every ten thousand output, according to the local agriculture bureau estimated data, basically all the area is dry land and main planting potatoes and corn, most region with no irrigation habits.

\subsubsection{The Ecological Environment Situation}

The zone mainly is a bare karst mountainous area, karst develops strongly, karst individual form such as surface sinkhole, funnel, depression etc. distribute densely, the reservoir and conduction system of karst groundwater is composed by fracture, cave, pipeline etc. The formation of underground-ground double space structure making karst underground water has strong self-purification capacity to pollutants, but the sensitivity to the pollution is much stronger.

Forest coverage rate of Weining county is about $30 \%$, the karst area accounted for $69.89 \%$ of the county total area, potential rocky desertification area in the karst area is $153384 \mathrm{hm} 2$, makes up $34.86 \%$ of karst area, and $24.36 \%$ of the total land area; Rocky desertification area is $110391 \mathrm{hm} 2$ and is $24.86 \%$ of karst area, $17.53 \%$ of the total land area, 35 townships of the whole county have undergone different degrees rocky desertification. Soil erosion is very serious and soil erosion modulus is about $2500 \mathrm{t} / \mathrm{km} 2 \cdot \mathrm{a}$.

\subsection{Index Quantification}

According to the method mentioned above, the determination of quantitative criteria in accordance with the standards in Table $\mathbf{2}$ and adopt 5 degree grading standard. The quantitative results are shown in Table 4.

\subsection{Index Weight Determination}

According to the analysis of the main control factors of groundwater venerability in karst area, use the "solicitation expert grading" method, collecting and consulting experts, colleges and scholar of scientific research units to grade the control factors that influencing karst area groundwater venerability. scoring criteria is in accordance with $1 \sim 9$ score method of the table 3, which was founded by SAATY, invite subject-matter experts to evaluate the relative importance of each factor and give quantify score; finally making overall score comparison according to the cumulative scores and forming the expert judgment set on various influencing factors, thus build judgment matrix of AHP of water inrush from seam floor. Firstly determine the weight value of the criteria layer, compare to the three evaluation criteria of the inherent vulnerability of groundwater, the vulnerability of ecological environment and the vulnerability of water resources carrying capacity, experts scoring method making two-two comparative judgment to each factor respectively and getting weight fuzzy complementary judgment matrix (Table 5).

According to the table, the CR value calculated from the matrix is less than 0.1 , with satisfactory consistency, judgment matrix can meet the consistency test. With the same method to determine the weight of criterion layer, in accordance with AHP and combine with the found weight of criteria layer, finally obtain the weight of each factor (Table 6). 
Table 5. Judgment matrix A Bi $(i=1 \sim 3)$.

\begin{tabular}{|c|c|c|c|c|}
\hline $\mathbf{A}$ & B1 & B2 & B3 & W (A/Bi) \\
\hline \hline B1 & 1 & 1 & 1 & 0.4126 \\
\hline B2 & 1 & 1 & 1 & 0.3274 \\
\hline B3 & $1 / 2$ & 1 & 0.2600 \\
\hline
\end{tabular}

$\lambda_{\max }=3, \quad \mathrm{CI}=0.02681, \quad \mathrm{CR}=0.04623<0.1$

Table 6. Calculation results of index weight $(i=1 \sim 19)$.

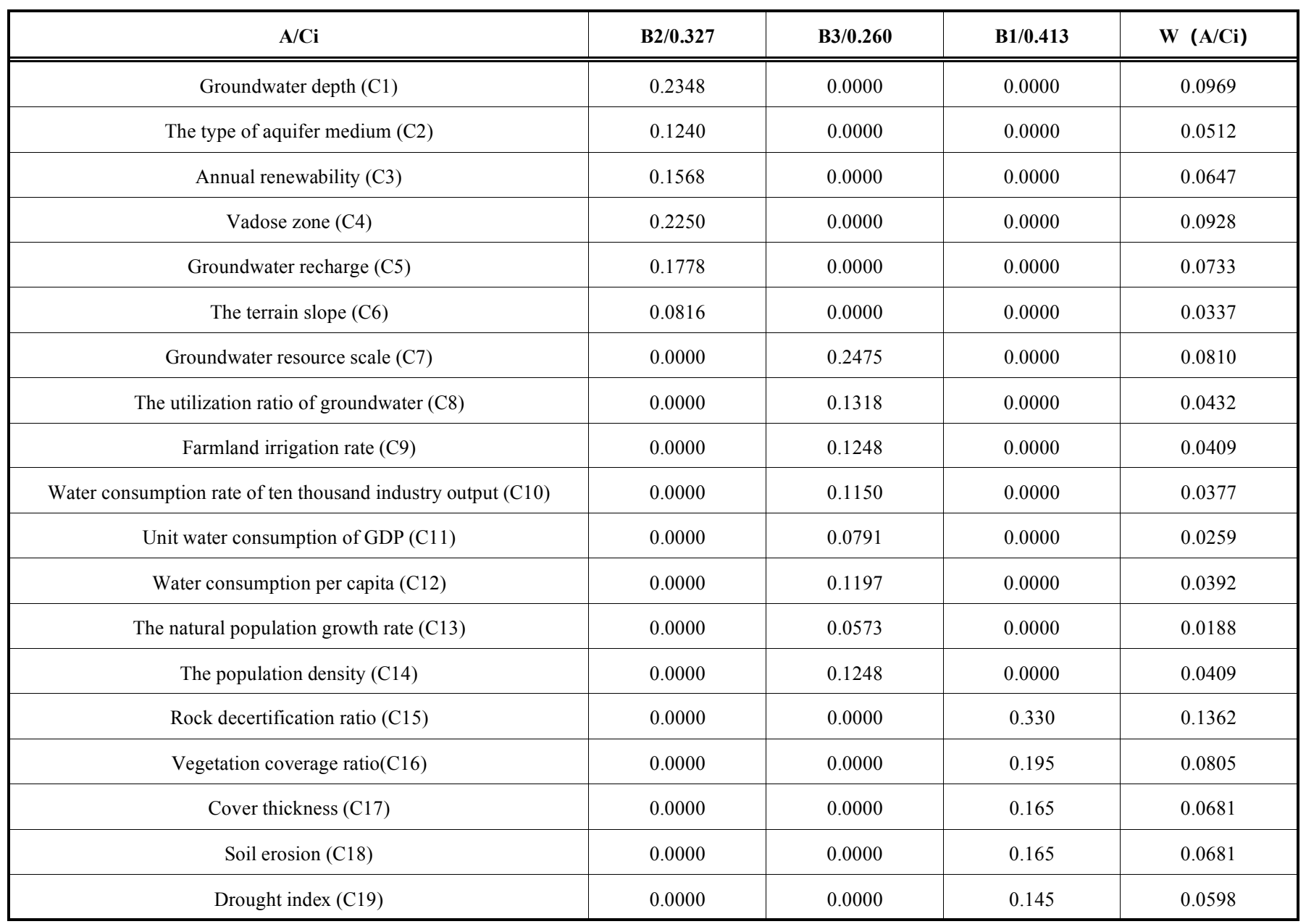

\subsection{The Comprehensive Evaluation}

Combining the weight calculate results and index quantification results, we can get the comprehensive index value of groundwater venerability $\mathrm{V}=\sum \mathrm{Ik} \times \mathrm{Wk}=1.982$. According to the evaluation criteria in table 2 , groundwater vulnerability of the study area is stronger vulnerable (grade II). The main reason as follows:

Weining county has lacked water for long times, groundwater occupancy per capita is very few, groundwater resource distributes unevenly. Engineering water shortage and water resources shortage coexist. Cover thickness of the karst area is thin, groundwater depth is shallow generally, the anti-pollution ability is weak. Excessive exploitation of groundwater caused many ecological environment problems, soil erosion is serious, desertification problem is prominent. Weining is a state poverty county, urbanization still needs speed up. The government investment fund is insufficient and the awareness of environmental protection should be improved. Considering the above factors, the assessment result of groundwater vulnerability in the study area is more consistent with reality.

\section{CONCLUSION}

The occurrence of groundwater resources in karst area has its own particularity, mainly is that groundwater system is sensitive to outside interference, carries on vulnerability assessment is conducive to protection and utilization of regional groundwater resources better. Based on the analysis 
and summarization on other groundwater vulnerability assessment methods, this paper proposes the point that groundwater venerability assessment should be composited by the inherent vulnerability of groundwater, the vulnerability of ecological environment and the vulnerability of water resources carrying capacity, establishing the index system of groundwater vulnerability assessment in karst area from the above three perspective, at the same time, the paper also put forward corresponding vulnerability assessment method combine with the AHP.

The paper apply the assessment method to the overall evaluation of groundwater venerability in Weining county, Guizhou province, where is typical karst area in China, at the same time combining with the actual conditions of the area to verify and good results have been achieved. The evaluation method provides a certain basis and reference for groundwater vulnerability assessment in similar karst area.

\section{CONFLICT OF INTEREST}

The author confirms that this article content has no conflicts of interest.

\section{ACKNOWLEDGEMENTS}

This research was financially supported by China National Natural Science Foundation (Grant no. 41261093), Guizhou Province Science and Technology Agency Foundation (qian ke he LH zi[2014]7617), Guizhou University Introducing Talents Research Foundation (2014-61).

\section{REFERENCES}

[1] Z. C. He, Vulnerability Assessment Research of Water Resources Systems Under Changing Environment, Science Press, Beijing 2011.
[2] M. A. Janssen, M. L. Schoon, W. Ke, K. Börner, "Scholarly networks on resilience, vulnerability and adaptation within the human dimensions of global environmental change," Global Environmental Change, vol. 16, pp. 240-252, 2006.

[3] D.X. Yuan, "Aspects on the new round land and resources survey in karst rock desertification areas of south China," Carsologica Sinica, Guilin , vol. 2, pp. 2-7, 2000.

[4] J. Vrba, and A. Zaporozec, "A Guidebook on mapping groundwater vulnerability," International Contributions to Hydrogeology Founded by Castany G, Groba E, Romijn E. Heise, vol. 16, pp. 131,1892 .

[5] National Research Council, Groundwater Vulnerability Assessment: Predicting Relative Contamination Potential Under Conditions of Uncertainty, National Academy Press, Washington 1993.

[6] R. C. Gogu, and A. Dassargues, "Current trends and future challenges in groundwater vulnerability assessment using over lay and index methods," Environmental Geology, vol. 39, pp. 549-559, 2000 .

[7] R.T. Liu, Q. Fu, W. Y. Li, Y. Feng, L. Guo, "Study on the groundwater vulnerability, "Journal of Water Resources and Water Engineering, vol. 17, pp. 1-59, 2006.

[8] N. Goldscheider, M. Klute, S. Sturm, H. Z. Angew, "The PI method-a GIS-based approach to mapping groundwater vulnerability with special consideration of karst aquifers," Zeitschrift für Angewandte Geologie, vol. 46, pp. 157-166, 2000.

[9] H. Bossel, Indicators for Sustainable Development: Theory, Method, Applications, International Institute for Sustainable Development, Winnipeg 1999.

[10] P. Satya, H. Abdel, S. Hussein, S. Abulifa, "Sustainable integrated water resources management for energy production and food security in Libya," The $7^{\text {th }}$ International Conference Interdisciplinarity in Engineering, Romania, Procedia Technology, vol. 12, pp. 747 752, 2013.

[11] D. Hellström, U. Jeppsson, E. Kärrman, "A framework for systems analysis of sustainable urban water management," Environmental Impact Assessment Review, vol. 20, pp. 311-321, 2000.

[12] T.L. Saaty, The Analytic Hierarchy Proeess, MeGraw-Hill, New York, 1980.

Received: January 09, 2015

(c) Bo Li; Licensee Bentham Open.

This is an open access article licensed under the terms of the (https://creativecommons.org/licenses/by/4.0/legalcode), which permits unrestricted, noncommercial use, distribution and reproduction in any medium, provided the work is properly cited. 